NBER WORKING PAPER SERIES

\title{
IMPORTING EQUALITY? \\ THE IMPACT OF GLOBALIZATION ON GENDER DISCRIMINATION
}

\author{
Sandra E. Black \\ Elizabeth Brainerd \\ Working Paper 9110 \\ http://www.nber.org/papers/w9110 \\ NATIONAL BUREAU OF ECONOMIC RESEARCH \\ 1050 Massachusetts Avenue \\ Cambridge, MA 02138
}

August 2002

The authors thank Francine Blau, Ralph Bradburd, Janet Currie, Rebecca Demsetz, Judith Hellerstein, Chinhui Juhn, William Pizer, Marc Saidenberg, and Joseph Tracy, along with seminar participants at the Federal Reserve Bank of New York, Hunter College, and Williams College for helpful comments and discussions. Special thanks to David Jaeger for providing the code to match census MSAs over time. Colleen Sellers and Jennifer Poole provided outstanding research assistance. The views expressed herein are those of the authors and not necessarily those of the National Bureau of Economic Research.

(C) 2002 by Sandra E. Black and Elizabeth Brainerd. All rights reserved. Short sections of text, not to exceed two paragraphs, may be quoted without explicit permission provided that full credit, including (C) notice, is given to the source. 
Importing Equality? The Impact of Globalization on Gender Discrimination

Sandra E. Black and Elizabeth Brainerd

NBER Working Paper No. 9110

August 2002

JEL No. J3, J7

\begin{abstract}
While researchers have long held that discrimination cannot endure in an increasingly competitive environment, there has been little work testing this dynamic process. This paper tests the hypothesis (based on Becker 1957) that increased competition resulting from globalization in the 1980s forced employers to reduce costly discrimination against women. The empirical strategy exploits differences in market structure across industries to identify the impact of trade on the gender wage gap: because concentrated industries face little competitive pressure to reduce discrimination, an increase in competition from increased trade should lead to a reduction in the gender wage gap. We compare the change in the residual gender wage gap between 1976 and 1993 in concentrated versus competitive manufacturing industries, using the latter as a control for changes in the gender wage gap that are unrelated to competitive pressures. We find that increased competition through trade did contribute to the relative improvement in female wages in concentrated relative to competitive industries, suggesting that, at least in this sense, trade may benefit women by reducing firms' ability to discriminate.
\end{abstract}

Sandra E. Black

Department of Economics

UCLA

Los Angeles, CA 90095

and NBER

310-825-5665

sblack@econ.ucla.edu
Elizabeth Brainerd

Department of Economics

Williams College

Williamstown, MA 02167

and CEPR

413-597-4375

elizabeth.brainerd@williams.edu 
In his seminal work on the economics of discrimination, Gary Becker (1957) made the startling claim that increased competition in the product market would reduce or eliminate discrimination against women and minorities in the long run. This implies a positive relationship between market power and employment discrimination: because discrimination is costly in the sense that discriminating employers forego profits in order to indulge their 'taste for discrimination', employers with market power will be able to practice discrimination to a greater extent than employers with little market power. The theory also has dynamic implications in that changes in the relative employment and earnings of the discriminated groups will depend in part on changes in market power. Focusing on women in particular, increased product market competition in an industry (or region) over time should reduce earnings and employment disparities between men and women, all else equal.

The recent narrowing of the gender earnings gap in an era of increased competition through international trade and deregulation might seem to offer supportive evidence of this theory. Since 1960, in fact, the gender wage ratio and the share of imports in GDP have followed similar time trends, with both series remaining fairly constant between 1960 and 1980, then increasing dramatically through the early 1990s (Figure 1). Despite this suggestive evidence, however, few researchers analyzing the causes of the improvement in female relative wages and employment have focused on the links between trade and gender discrimination. Recent analysis of female wage gains in the 1980s, for example, concludes that women's gains in work experience and occupational status explain much of the improvement in women's relative wages; improvements in unobserved characteristics and reduced labor market discrimination against women likely contributed as well (Blau and Kahn 1997). ${ }^{1}$ While economists have suggested a

\footnotetext{
${ }^{1}$ Other important contributions to understanding changes in the gender wage gap include Goldin (1990) and
} 
number of plausible reasons for declining gender discrimination in the labor market - despite waning federal anti-discrimination efforts in recent years - the idea that women may have benefited from increased product market competition resulting from increased trade has not been explored. This paper tests the hypothesis, based on Becker's theory, that increased competition in the 1980s forced employers to reduce costly discrimination against women and thus contributed to the improvement in female labor market status in that period.

Did employers face increased competition in the 1980s? At least in some industries, it appears that they did: a number of industries faced deregulation in the mid-to-late 1970s and early 1980s (such as the banking, trucking, telecommunications and airline industries), and many industries confronted intensified competition in the form of increased imports from foreign competitors. This paper focuses on the latter form of increased competition, and attempts to answer the question: has increased trade led to a decline in discrimination and, as a result, contributed to the improvement in relative female wages? Did the market step in where the federal government left off, and force (at least some) employers to reduce discrimination in order to remain viable in an increasingly competitive world?

We test this idea using both the Current Population Survey and the 1980 and 1990 Censuses, and examine the relationship between changes in trade and changes in the gender wage gap across industries as well as across metropolitan areas. The wage data are broken down by concentrated and competitive industries. Since concentrated industries face little competitive pressure to reduce discrimination, an increase in competition from increased trade should lead to a greater reduction in the gender wage gap than in competitive industries also hit by trade. We

\footnotetext{
O'Neill and Polachek (1993); Blau (1998) provides a broad overview of changes in the economic status of women from 1970 to 1995 .
} 
compare the change in the gender wage gap in trade-impacted concentrated versus

unconcentrated sectors, using the latter as a control for changes in the gender wage gap that are unrelated to competitive pressures.

The positive perspective on trade implicitly adopted in this idea contradicts the spirit of recent research on the links between trade and the structure of wages; this research has largely focused on the contribution of trade to rising wage inequality in the United States, and particularly on the link between trade and the deteriorating fortunes of less skilled workers. While analysts disagree on the size of the impact of trade on wage inequality and relative employment, there is little disagreement over the sign: for less skilled workers, trade hurts. ${ }^{2}$ Our results indicate that, in contrast to this perspective, trade may actually benefit some groups of workers - at least in a relative sense - by reducing the ability of firms to discriminate. ${ }^{3}$

\section{Conceptual framework}

\section{A. The Becker model of employer discrimination}

Becker's 1957 treatise on discrimination began by focusing on employers' personal preferences as a source of discrimination, arguing that some employers had a 'taste for discrimination' and would be willing to pay to indulge this taste. ${ }^{4}$ As Gary Becker himself put it

${ }^{2}$ For an overview of the literature on trade and wage inequality, see Freeman (1995) and the references therein.

${ }^{3}$ Note that increased competition can make discriminated workers absolutely worse off but relatively better off, if the firm eliminates both the rents it previously shared with workers and the gender (or racial) wage gap in response to increased competition.

${ }^{4}$ Becker also analyzed the effects of discrimination by co-workers and by customers; the focus here is on his model of employer discrimination. 
some forty-five years ago:

If an individual has a "taste for discrimination," he must act as if he were willing to pay something, either directly or in the form of a reduced income, to be associated with some persons instead of others. When actual discrimination occurs, he must, in fact, either pay or forfeit income for this privilege. This simple way of looking at the matter gets at the essence of prejudice and discrimination. (p. 14)

Employers with a 'taste for discrimination' against women will hire fewer than the profitmaximizing number of women, employing more men who are equally skilled yet more highly paid. As a result, non-discriminating employers can drive discriminating employers out of the market because discrimination is costly: employers who discriminate against women sacrifice profits in order to indulge their taste for discrimination. In an increasingly competitive market, the wage gap between men and women of equal skills will narrow and may - under certain conditions - eventually disappear, as discriminators are forced by market pressure to change their discriminatory practices or are bought out by non-discriminating firms. ${ }^{5}$

Product market competition plays an important role in these ideas, suggesting a link between market structure and the ability of an employer to practice discrimination: discriminating employers with market power, (presumably) earning positive economic profits, will be able to survive longer in the market than those operating in a competitive market with

${ }^{5}$ See Becker (1957), Goldberg (1982), and Heckman (1998) for more detailed discussions regarding the conditions required for this relationship to hold. While other empirical tests of Becker's hypothesis (discussed below) have focused on the narrowing of the employment gap implied by the theory, this paper focuses on the narrowing of the wage gap between discriminated and nondiscriminated groups. Becker argues that the wage gap will narrow because firms employing the discriminated group (who earn lower wages) will expand relative to firms employing the nondiscriminated group, and this will increase the wages of the discriminated group relative to the wages of the non-discriminated group (Becker 1971, p. 44). 
zero economic profits. Therefore, the gender wage gap should be smaller in competitive markets than in concentrated markets, all else equal. This prediction appears to provide a relatively simple test of the neoclassical theory of labor market discrimination.

A strand of the literature on labor market discrimination has focused on testing this implication of Becker's theory regarding the relationship between market power and discriminatory practices. One of the most compelling studies in this vein examined employment practices in the banking industry, and found a negative and statistically significant relationship between market power in local banks and the share of female employment in each bank - thus confirming the predictions of Becker's theory (Ashenfelter and Hannan 1986). ${ }^{6}$ More recently, Black and Strahan (2001) study how the deregulation in the banking industry since the mid1970s affected banks' ability to share rents with favored workers. They find that banks did share rents disproportionately with men and that deregulation reduced this practice and significantly improved the relative wages of women. Hellerstein, Neumark and Troske (2002) test the relationship between profits and female employment across firms with market power and find that firms that employ relatively more women have higher profits, as the theory predicts. They also test whether firms that discriminate grow more slowly than firms that do not discriminate but find little support for this hypothesis. However, the five-year period they examine regarding the latter hypothesis is probably too short to adequately test that relationship.

Unlike most previous researchers, we choose to focus our analysis on one of the key dynamic implications of the Becker model-- that changes in the competitive environment will lead to changes in the gender wage differential--rather than examining the static correlation

\footnotetext{
${ }^{6}$ This study also summarizes the early evidence from other studies on the relationship between
} employment discrimination and product market power. 
between product market competition and the gender wage (or employment) gap at any one point in time. We take this approach because the primary concern is understanding the apparent change in labor market discrimination against women in the 1980s and 1990s.

\section{B. Methodology}

Testing the simple prediction that increased competition from trade leads to declining discrimination against women and thus a declining gender wage gap is less straightforward than it appears, however. In considering the period from the late 1970s to the present, for example, it is evident that there are numerous reasons why the gap between female and male wages has narrowed over this period, and many of these reasons are unrelated to increased competitiveness in product markets. The increases in women's educational attainment, for example, may complicate the empirical analysis with the possibility of a misleading link between trade and the gender wage gap. If, for some reason, women's educational attainment increased by more in trade-impacted industries than in non-trade-impacted industries, simple empirical tests may indicate that trade contributed to the narrowing of the differential, rather than the underlying true cause of increased female labor market experience. Therefore it will be important to control for differing changes in observable characteristics across industries and regions that may confound the results. As a first step toward this goal, we test the links between trade and the residual gender wage gap, i.e. the gender wage gap that remains after one controls for differences in education and potential labor market experience between men and women.

It is equally important to control, if possible, for differing changes in women's unobserved characteristics that may have contributed to differing improvements in relative female pay across industries; such changes are speculated to have contributed to the narrowing of 
the 'unexplained' portion of the gender wage gap in the 1980s (Blau and Kahn 1997). These unobserved characteristics might include, for example, a stronger commitment to the labor force or to one's career, or to improved ability or underlying productivity of women relative to men.

In order to purge our estimates of bias due to these omitted variables, we use a methodology that (conceptually) groups our observations along two lines: (1) industries that were and were not affected by a trade shock in the period under study and (2) concentrated and competitive industries. This estimator will eliminate bias due to omitted variables that (1) have a common value for all trade-impacted or non-trade-impacted industries, such as shocks to economic conditions in manufacturing industries and (2) have a common value for all concentrated or competitive industries, such as worker ability or labor force attachment. In other words, the results indicate the impact of trade on the gender wage gap in concentrated industries relative to competitive industries, netting out any factors that have affected the gender wage gap in manufacturing industries, trade-impacted industries as a whole or concentrated industries as a whole. ${ }^{7}$ Conceptually we calculate the following differences in the gender wage gap (note that, in practice, we allow the impact of trade to be continuous and not discrete):

$$
\left(\begin{array}{cc}
\text { trade impacted } \\
\text { concentrated }
\end{array}-\begin{array}{c}
\text { non-trade impacted } \\
\text { concentrated }
\end{array}\right)-\left(\begin{array}{cc}
\text { trade impacted } \\
\text { competitive }
\end{array}-\begin{array}{c}
\text { non-trade impacted } \\
\text { competitive }
\end{array}\right)
$$

which is equivalent to estimating the following equation:

${ }^{7}$ Although trade may have similar effects in the non-manufacturing sector, the empirical analysis focuses on the manufacturing sector because trade data are unavailable for the non-manufacturing sector. In addition, several industries in the non-manufacturing sector were affected by deregulation during the same time period (for example, trucking, airlines, banking, and telecommunications), and it would be difficult to isolate these effects from the effects of trade. 


$$
\Delta_{i}\left(\operatorname { l n } \left(\text { wage }_{i m}-\ln \left(\text { wage }_{i f}\right)=\alpha+\beta \Delta_{i} \text { trade }_{i}+\gamma \text { concen }_{i}+\psi\left(\Delta_{t} \text { trade }^{2} \text { concen }\right)_{i}\right.\right.
$$

where $\Delta_{t}$ trade $_{i}$ is the change in the import share in industry $i$, and concen $_{i}$ is an indicator variable equal to one if the industry was concentrated in $1977 .^{8}$ The inclusion of the dummy variable for concentrated industries allows for a differential change in the gender wage gap for concentrated industries relative to competitive industries. The marginal effect of trade on concentrated industries relative to competitive industries is represented by the $\psi$ coefficient; this is the primary parameter of interest.

This approach implicitly makes two assumptions. First, it assumes that discrimination against women did (or does) indeed exist, at least at the beginning of the period under study, and that this discrimination was reflected in lower wages for women relative to equally skilled men. While clearly a controversial issue, several recent careful studies suggest that this is the case. Two of these studies compared men and women with very similar human capital investments and labor market skills, and found that a wage gap of 10 - 15 percent still exists even when one includes detailed controls for work and skill characteristics (Wood, Corcoran and Courant 1993; Weinberger 1998). Similarly, an audit study of hiring in Philadelphia restaurants found that

\footnotetext{
${ }^{8}$ This approach is similar in spirit to that of Borjas and Ramey (1995), which examines the relationship between wage inequality and foreign competition by comparing the effect of imports in concentrated versus competitive industries. As in that work, we also use 1977 concentration ratios to determine if an industry is concentrated and do not let this vary over the sample time period. Increased competition due to increased trade could affect the concentration ratio in the industry; as a result, we do not allow concentration to vary over this time period in order to capture the full impact of trade on competition.
} 
high-priced restaurants were substantially more likely to interview and make job offers to men over women with comparable work experience (Neumark 1996). These studies suggest that gender discrimination did persist, at least in the 1980s and early 1990s. ${ }^{9}$

The second assumption implicit in this methodology is that increased imports are equivalent to an increase in competition within an industry. Several studies document that this assumption appears to hold in practice; for example Levinsohn (1993) uses firm-level data for Turkey to test the impact of the wide-ranging trade liberalization adopted in 1984 on pricemarginal cost ratios, and provides persuasive evidence that the removal of import protection in manufacturing industries reduced markups in firms in imperfectly competitive industries. Using industry-level data for the United States, Katics and Petersen (1994) also find that increased import competition reduced price-cost margins during the 1976-1986 period. Although these issues are far from settled, based on current research we are reasonably confident that the two assumptions regarding discrimination and the impact of imports on competition hold during the period under study.

\section{Data}

The primary data source for the empirical work is the March Demographic Supplement to

${ }^{9}$ The persistence of wage differentials across industries raises the question as to why women have not simply moved from low- to high-paying industries, thus eliminating gender wage differentials across industries over time. Recent evidence in the banking industry suggests that industries may be sharing rents with workers and disproportionately with male workers. As a result, women - although earning less than their male counterparts - may still be earning a wage above the competitive wage and hence have no incentive to leave despite the discriminatory behavior. See Black and Strahan (2001). 
the Current Population Survey (CPS) from 1977 through 1994. Although this data set is not ideal for the test outlined above - in particular it lacks a measure of actual labor market experience - it is preferable to other large data sets due to the relatively long time period over which consistent measures of income and other variables are available, and due to the large sample sizes which enable analysis across industries and metropolitan areas. The 1977 - 1994 period is chosen because 1977 was the first year in which a relatively large number of metropolitan areas is identified in the CPS, and trade data are available only through 1994.

The sample is defined similarly to that in Borjas and Ramey (1995), which in turn matched many of the data refinements described in Katz and Murphy's (1992) study of the wage structure. The sample includes individuals aged 18 to 64 who worked full-time in the civilian sector in the year prior to the survey; a "full-time" worker is defined as one who worked at least thirty hours in their usual work week and worked more than 48 weeks in the previous year. Selfemployed individuals and individuals working without pay are excluded from the analysis. The wage data refer to real weekly or hourly earnings in the previous year in 1982 dollars; wages were deflated by the Consumer Price Index. As in the works cited above, workers earning less than $\$ 67$ in weekly wages in 1982 dollars are excluded from the analysis, and the wages of workers whose earnings are topcoded are multiplied by 1.45 . Industries in which male or female employment comprises less than 10 percent of total employment are also excluded from the sample. Because trade data are available only for the manufacturing sector, the analysis uses only workers employed in the manufacturing sector of the economy.

Two additional sources of information on earnings, work and demographic characteristics are used to test the sensitivity of the results to the choice of data set: the 1980 and 1990 
Censuses, and the Outgoing Rotation Groups of the CPS. ${ }^{10}$ The codes for the Metropolitan Statistical Area (MSA) in the Censuses were matched over time in a manner consistent with Jaeger et al (1998).

The trade data are from the National Bureau of Economic Research (NBER) Trade Database compiled by Robert Feenstra (1996). The impact of trade on an industry is measured using import shares, which are calculated as the ratio of imports (measured as the cost in freight (CIF) value of imports) to domestic shipments; the latter data are from the NBER Manufacturing Productivity database and are described in Bartelsman and Gray (1996). ${ }^{11}$ The industry-level import shares are aggregated at the three-digit level based on the 1980 Census definition. Across MSAs, the impact of trade is measured as the import share for the MSA, calculated as the average of the import shares of the industries in the MSA weighted by the number of workers in that industry in that MSA.

An industry is classified as a concentrated industry if the four-firm concentration ratio

${ }^{10}$ Census data were obtained from the IPUMS project at the University of Minnesota. For more information, see Rugles and Sobek (1997) or their webpage at http://www.ipums.umn.edu.

${ }^{11}$ Although one could also use (imports + exports)/domestic shipments as a measure of the impact of trade, many recent studies examining the relationship between trade and labor market outcomes have used the import share measure, so the same practice is followed here. See Borjas and Ramey (1995), Horn and Eastman (1997) and Kletzer (1996a, 1996b) for studies that follow this approach. Note that import shares are a conservative measure of the impact of trade on an industry: the threat of imports alone may force employers to act more competitively and reduce discrimination. As a result, the import share measure likely underestimates the impact of trade on employer behavior. We tested the sensitivity of our results by using (imports+exports)/domestic shipments as a measure of the impact of trade; the results were consistent with those presented here. 
was .40 or greater in 1977, based on the Census of Manufacturers conducted in that year. ${ }^{12}$ This determination was made at the beginning of the sample period in order to exclude the possibility that changes in concentration were due to increased trade. Appendix Table A lists the concentrated and non-concentrated industries in the sample based on this definition. ${ }^{13}$

Finally, the dependent variable used for most of the analysis is the change in the residual gender wage gap over the period. To calculate this variable, the log wage is first regressed on four categorical education variables, age, age squared, and a non-white dummy variable; this regression is estimated for the pooled sample of men and women in each year of interest. ${ }^{14}$ The residual gender wage gap is then generated as the difference in the average residual wage for men and women, calculated at the industry- or MSA-level. Although one could also include controls for occupation in the log wage equation, they are excluded here because one form of discrimination against women may have occurred through the types of jobs available to them. By excluding any controls for occupation, the results will measure the effect of increased competition through trade on employers' behavior regarding wages directly as well as indirectly through occupational changes.

\footnotetext{
${ }^{12}$ We tested the sensitivity of the results to this choice of a cutoff and found the results to be insensitive to concentration ratios ranging from .30 to .50. Following Borjas and Ramey (1995), a CIC manufacturing industry was considered concentrated if the majority of workers in the industry were in concentrated four-digit (SIC) industries.

${ }^{13}$ Note that a few industries were dropped due to missing trade data. The industries included in our sample are listed in Appendix Table A.

${ }^{14}$ The four education categories are: less than high school, high school, some college, and college or more. These education classifications are reasonably consistent with those suggested in Jaeger (1997).
} 
Given that this study uses the change in the gender wage gap as the dependent variable, which is in itself a difference in log (residual) wages, it is clear that measurement error in this variable may affect the precision of the estimates. As discussed in Angrist and Krueger (1998) and Bound et al (1994), the reliability of earnings data declines when earnings are expressed as year-to-year changes rather than as levels. Although this measurement error does not bias the coefficient estimates, it does increase the standard errors of the coefficient estimates and thus reduces the statistical significance of the results. On the other hand, the above studies also indicate that the reliability of earnings estimates increases when one analyzes changes in earnings over longer periods; because this study examines changes over a seventeen-year period, it is less likely that measurement error will affect the results in a significant way.

\section{Results}

Table 1 reports the results of estimating equation (1) using data from the March CPS across manufacturing industries over the $1976-1993$ period. ${ }^{15}$ In this equation, the change in the industry-level residual gender wage gap is regressed on the change in the import share in the industry over the period, a dummy variable that equals one if the industry was concentrated in the beginning of the period, and the interaction of these two terms. The dependent variable is the change in the residual gender wage gap from 1976 to 1993, so that declines in this variable indicate improving female relative wages over the period.

The positive and statistically significant coefficient on the concentrated industry dummy variable in the first column of Table 1 indicates that the residual gender wage gap increased in

\footnotetext{
${ }^{15}$ The observations are weighted by the inverse of the sampling variance of the dependent
} variable. 
concentrated industries relative to competitive industries, or in other words the gender wage gap declined more in competitive industries than in concentrated industries. The positive coefficient on the 'change in import share' variable indicates that the gender wage gap grew more in industries that experienced greater increases in imports relative to industries that experienced little or no competition from increased trade. While this result may appear to contradict the theory discussed above - i.e., that if trade is a form of competition, increased trade in an industry should reduce the gender wage gap relative to industries with no increase in trade - a second effect of trade on relative wages would work in the opposite direction. This effect is the impact of trade on the wages of less-skilled workers relative to more-skilled workers: if trade disproportionately hurts less-skilled workers, as recent research has suggested, ${ }^{16}$ and women comprise a disproportionate share of less-skilled workers, then trade will also affect the relative wages of men and women through this route. If this is the case, one would expect trade to reduce women's wages relative to men's wages, and an increase in the gender wage gap should be observed in trade-impacted industries (or, the gender wage gap should narrow more slowly in trade-impacted industries). Women may be less skilled than men in the sense that they have less actual labor market experience than men; this has been shown to be an important factor in explaining changes in the gender wage gap (Blau and Kahn 1997).

The key variable of interest for this paper, however, is the interaction between the concentrated industry dummy variable and the change in import share variable. A negative coefficient would indicate that the gender wage gap has declined more in concentrated industries that experienced a trade shock relative to competitive industries that were also affected by trade. The coefficient on this term is indeed negative and statistically significant, indicating that trade-

\footnotetext{
${ }^{16}$ See, for example, Murphy and Welch (1991), Wood (1994), and Borjas and Ramey (1995).
} 
impacted, concentrated industries do in fact experience reductions in their residual gender wage gap relative to competitive industries also hit by trade. The coefficient suggests that a 10 percentage point increase in import share in a concentrated industry would lead to approximately a 6.6 percent decline in the residual gender wage gap. The standardized coefficient is presented in brackets. ${ }^{17}$ To understand the economic importance of this estimate, the average increase in import share in concentrated industries accounts for a decline in the residual gender wage gap in manufacturing of approximately $.034 \log$ points. (The overall decline in the residual gender wage gap in manufacturing was approximately $.14 \log$ points during this period.) However, this positive effect is offset by the rising residual gender wage gap in concentrated industries relative to competitive industries and by the rising residual gender wage gap due to increasing imports as a whole.

The second column of Table 1 shows the results of estimating equation (1) using the residual gender wage gap of hourly earnings as the dependent variable; the coefficient estimates are similar to those in column 1, indicating that the results are insensitive to the choice of weekly versus hourly wages. The third column of Table 1 uses an alternative measure of industry concentration, the price-cost $\operatorname{margin}^{18}$, to examine whether the results are sensitive to the measure of market structure chosen. As shown in column 3, the key coefficient of interest remains negative and statistically significant. The last two columns of Table 1 increase the number of

${ }^{17}$ Standardized coefficients are presented to enable comparison across different regressions. The standardized coefficient is the estimated coefficient multiplied by (standard deviation of the independent variable / standard deviation of the dependent variable).

${ }^{18}$ The price-cost margin is defined as (value added - labor costs)/total sales and was collected from the Census of Manufacturers. 
observations by dividing the time period into two periods (the nine-year differences) and three periods (the six-year differences), respectively, and include time dummies as well. In both cases, the interaction between concentrated industry and change in import share remains negative, and the standardized coefficients suggest that the magnitudes are similar. The coefficient is statistically significant at the $2.9 \%$ level for the 9 -year differences and at the $15 \%$ level for the 6 year differences, suggesting that measurement error becomes an increasing problem as the sample is divided into smaller and smaller time periods as one would expect. ${ }^{19}$

Table 2 tests the sensitivity of these results to the choice of data set. While the March CPS is an appropriate data set in the sense that its sample size is larger than that of any longitudinal survey and because it contains consistent measures of the variables of interest over the entire period under study, it is limited in that the cell sizes used for estimating equation (1) (i.e., industry by year by gender) may be small. To increase the cell size, equation (1) is also estimated using the CPS Outgoing Rotation Group surveys as well as the 1980 and 1990 Censuses.

The CPS Outgoing Rotation Group surveys are approximately three times larger than the March supplement, a strong advantage for the empirical work undertaken here. However, the Outgoing Rotation Group begins only in 1979, and it does not include information on the number of weeks worked in the previous year. The latter problem prevents us from conditioning on strong labor force attachment (number of weeks worked) as we did with the March CPS. Despite

${ }^{19}$ Finally, we also estimated the basic regressions in Table 1 using the individual as the level of analysis while correcting the standard errors for clustering by industry. The results are nearly identical to those presented in Table 1 and are omitted here for brevity. 
these differences, however, the results presented in the first two columns of Table 2 using the Outgoing Rotation Groups are quite similar to those of Table 1 that used the March CPS. The coefficient on the interaction of concentrated industry and change in import share is still negative (and still significant, although marginally); in addition the standardized coefficient suggests a magnitude consistent with the estimates based on the March CPS. In both of these regressions the change in import share variable is no longer statistically significant.

The last column of Table 2 presents the results using the 1980 and 1990 Censuses 1\% sample. The obvious advantage in using Census data is that the sample size is extremely large and therefore the industry cell sizes are much larger than in the case of both CPS data sets. However, because the data span only ten years, there is less variation in the change in import shares over the period..$^{20}$ Nevertheless, the estimated coefficient on the interaction term is still negative and statistically significant and, again, of the order of magnitude suggested by the other data sets.

To this point, the analysis has focused on testing the impact of trade across industries. This is appropriate because we are interested in how trade, as a form of increased competition, differentially affects wages in competitive versus concentrated manufacturing industries. ${ }^{21}$ This approach would be less appropriate if one believed that the changes in the gender wage gap in manufacturing industries due to increased trade had spillover effects into non-manufacturing

${ }^{20}$ The 1970 Census is not used because there are fewer MSA indicators in that Census than in the later Censuses.

${ }^{21}$ Numerous other studies use industry-level data to examine the effects of trade; see, for example Kruse (1988), Revenga (1992), Gaston and Trefler (1994), Kletzer (1996a, 1996b), Horn and Eastman (1997), and Campa and Goldberg (1998). 
industries. This argument, for example, is similar to the argument given in Borjas and Ramey (1995) for analyzing the impact of trade on skill differentials across metropolitan areas rather than across industries. In that paper, the authors argue that the declining relative wages and employment of less-skilled workers in concentrated industries due to trade had spillover effects on the wages of less-skilled workers in the competitive sector of the economy; as a result it is appropriate to analyze the impact of trade across local labor markets rather than across industries.

While spillover effects are unlikely to be strong in the case of changes in the gender wage gap, we nevertheless test the sensitivity of the results to this assumption by estimating equation (1) at the MSA level. The results of these tests are presented in Table 3; the tests are conducted using both the March CPS and the 1980 and 1990 Censuses. ${ }^{22}$ In this case, the MSA residual gender wage gap is calculated as the employment-weighted average of the residual gender wage gap for each industry in manufacturing in the MSA. ${ }^{23}$ The import share is calculated similarly, as the employment-weighted average of the import share in each manufacturing industry in the MSA; the concentration variable is defined as the share of workers employed in a concentrated industry in the MSA.

As indicated in Table 3, the results at the MSA level are essentially the same as the estimates at the industry level. The coefficients appear larger, but this is because the interaction term is now the percentage of employment in the MSA that is in concentrated industries, interacted with the change in the import share at the MSA level, instead of a zero-one dummy

${ }^{22}$ The CPS Outgoing Rotation Group data sets are not used for the MSA level estimation because they lack consistent MSA identifiers over the relevant time period.

${ }^{23} \mathrm{We}$ include only manufacturing workers in the MSA estimation. This assumes that manufacturing and non-manufacturing workers are not close substitutes for one another. 
variable indicating whether or not an industry is concentrated interacted with the increased trade at the industry level. The first two columns show the results of estimating equation (1) across MSAs using the March CPS over the entire 1976 - 1993 period, using weekly and hourly earnings, respectively. These results are consistent with the industry level results, and the coefficients on the interaction term are negative and significant. The results are also similar when the 1980 and 1990 Census data are used, but the interaction term is no longer statistically significant. Note that the adjusted R-squared is negative in all cases, suggesting that these regressions explain little of the variation in the changes in the residual gender wage gap across metropolitan areas. This is likely due in part to the relatively small variation in import shares and concentrated industries across MSAs compared with the variation in these variables across industries (see Appendix Table 1 for means and standard deviations of these and other variables).

\section{Robustness Checks}

One factor that may affect the results and that has thus far been omitted from the discussion is the change in unionization rates over the period. If, as seems likely, concentrated industries tended to be more unionized than competitive industries, and men are more highly unionized on average than women, then the decline in unionization rates over this period would likely reduce the gender wage gap more in concentrated industries than in competitive industries. Moreover, if import shares rose more in concentrated industries than in competitive industries during this time, the change in the import share in these regressions may simply be acting as a proxy for the change in unionization rates, and the results may simply reflect the impact of the erosion of union power rather than the impact of trade on the wage structure. To test this possibility, column 1 of Table 4 includes the change in the percentage of workers unionized in 
each industry in the regression. The results are virtually identical to those without unionization, suggesting that the results do not reflect changes in unionization rates within industries. ${ }^{24}$

Another factor that may affect the results is technological change. In order to obtain the results we observe, it would have to be the case that trade-impacted competitive industries faced more skill-biased technological change over this time period relative to trade-impacted concentrated industries. The technological change would increase demand for skilled workers, driving up the wages for skills, both observed and unobserved. Because women are disproportionately low-skilled, one would observe a rise in the gender wage gap in tradeimpacted competitive industries relative to trade-impacted concentrated industries. ${ }^{25}$ In order to test this theory, we regressed the percentage of workers who are college-educated (as a proxy for skilled workers) in each industry on the same independent variables as above. If observable skills change differentially by concentrated and trade-impacted industries, this might suggest that unobservable skills are changing in a similar manner and therefore that skill-biased technological change is driving the results. However, when we do estimate the relationship between skill composition and concentrated trade-impacted industries relative to trade-impacted competitive industries, we find no evidence that demand for skilled workers increased in trade-impacted

\footnotetext{
${ }^{24}$ Note that changes in unionization and trade are likely related to one another; see Horn and Eastman (1997) for an analysis of the impact of increased trade on union density. A variable for the interaction between unionization and concentration in this regression is negative and statistically significant; however the sign and significance of the primary interaction term remains unchanged.

${ }^{25}$ Note that, because we are controlling for education and age, these changes would have to be based on unobservable skills and not just observable skills, assuming that unobserved skill is correlated with observed skill.
} 
competitive industries relative to trade-impacted concentrated industries. In other words, the coefficient on the interaction term is statistically insignificant. ${ }^{26}$

As a second test of the technological change explanation, we also regressed the percentage of workers who use a computer at work on the same set of independent variables; this measure is intended to more directly capture the pace of technological change across industries in the workplace. The data on computer use are from the October CPS, which asked questions about computer use in the workplace in 1984, 1989, and 1993. The results indicate that, while industries experiencing a greater trade shock were slower to implement technological change in the form of computer use, there was no interaction effect between this measure of technological change and changing import shares (Table 4, column 2). This provides supportive evidence that a trade-technology interaction does not explain the results, i.e. that concentration is not simply acting as a proxy for technology. Column 3 of Table 4 indicates that, over the period examined in these regressions (1984-1993), the main results of interest continue to hold.

An additional factor that may affect the results is the choice of the time period over which the regressions are estimated. Several tests of the sensitivity of the results to this choice have already been conducted, through the use of the CPS Outgoing Rotation Group and Census data sets which restricted the analysis to years other than those tested in the original specification. Specifically, we have shown that the results hold whether the initial period is 1976 (March CPS),

\footnotetext{
${ }^{26}$ In addition to education, actual labor market experience is another possible proxy for skill that may explain the results. Experience would have to change differentially in concentrated relative to competitive industries impacted by trade in order to explain our results. Unfortunately, however, we are unable to test this possibility because the data sets used in the paper lack information on actual labor market experience.
} 
1979 (CPS-ORG), 1980 (Census), or 1984, and whether the end period is 1990 (Census) or 1993 (March CPS and CPS-ORG). ${ }^{27}$

Finally, two additional specification tests are implemented in order to verify that increased competition through trade does indeed reduce the ability of employers to discriminate. These tests are based on further predictions of the Becker employer discrimination model, one regarding the relative employment of women and the other regarding the relative wage of minorities. Regarding the former, Becker's theory predicts that as discrimination is driven away, not only will women's relative wages increase but their relative employment will increase as well. We have already shown that as competition increases, women's relative wages increase. We now test the second prediction of the theory: that women's relative employment will increase as well. The fourth column of Table 4 reports the results of regressing the change in the percentage of women employed in an industry on the same right-hand side variables: the concentrated industry dummy, the change in import share over the 1976-1993 period, and the interaction of the two terms. Although it is statistically significant at only the 15 percent level, the positive coefficient on the interaction suggests that as industries face more competition from international trade, concentrated industries increase their relative employment of women more

${ }^{27}$ Additional sensitivity tests indicate that the results are similar if 1991 or 1992 is used as the final year; this demonstrates that the results are not influenced by the CPS redesign that affected the 1993 earnings data but not the 1991 or 1992 earnings data. The only year and dataset for which the results fail to hold is the1994 March CPS. However, because the results do hold using the 1994 CPS-ORG dataset (the interaction term is statistically significant at the 5 percent level for both the weekly and hourly earnings specifications) and given the robustness of the results to other endpoints, we conclude that the 1994 March CPS results are anomalous and that overall the model is robust to the choice of time period used in the analysis. 
than competitive industries do. ${ }^{28}$

Another possibility is that women fail to advance out of less-skilled occupations as a result of discrimination. To test this, we examine whether increased trade affects the percentage of managers in manufacturing who are women. Column 5 shows that concentrated industries that face more competition from international trade increased the percentage of managers who are women, and that this result is statistically significant. These results are consistent with Becker's prediction and lends further support to the idea that trade has induced employers to reduce costly discrimination against women. ${ }^{29}$

Since Becker's theory originally attempted to explain the consequences of racial discrimination, it is fitting to test whether the same predictions regarding wage differentials and market competition hold if one examines the racial wage gap rather than the gender wage gap. Although the forces influencing the relative wages of minorities may have differed greatly from those influencing the relative wages of women in this period, one might still expect competitive pressures to affect a firm's ability to discriminate against minorities in the same way that competitive pressures would affect its ability to discriminate against women. Therefore, a final test is to examine how the minority residual wage gap (defined as the difference in the average

${ }^{28}$ These gains in female relative employment also suggest that the improvement in relative female wages in trade-impacted, concentrated industries was not due to women disproportionately dropping out of the labor force due to the impact of trade in these industries.

${ }^{29}$ Note that a concern is that our results are picking up a relative demand shift that favored female-dominated occupations. One counter to this argument is that we find similar results when we look within broadly defined occupation groups (in this case, managers). The fact that we find similar results provides support for the notion that it is a change in discriminatory practices and not an acrossoccupation demand shift. 
residual wage of white men in an industry minus the average residual wage of nonwhite men in an industry) in a concentrated industry is affected by trade relative to how the gap in a competitive industry is affected by trade. Because of the limited number of minorities working in the manufacturing industries in the sample, we use the CPS Outgoing Rotation data set to increase the sample size. Table 4, Column 6 presents the results of estimating equation (1) using the change in the minority residual wage gap from 1979 to 1993 as the dependent variable. Although not statistically significant, the coefficient on the interaction term is negative and of the same magnitude as earlier estimates for the gender wage gap. This lends further support to the hypothesis that increased competition through trade reduces the employer's ability to discriminate, and is particularly compelling because, unlike the gender wage gap, the racial wage gap did not narrow during this period.

\section{Conclusion}

Theory predicts that product market competition will drive out discrimination in the labor market. Because discrimination is costly in the sense that discriminating employers must forego profits in order to indulge their "taste for discrimination," firms with market power can afford to continue discriminatory practices for longer than can firms in competitive markets earning zero economic profits. Thus, the loss of market power in an industry is likely to reduce discrimination and increase the relative wages and employment of women in that industry. While a number of studies have demonstrated the apparent existence of discrimination, few studies have focused on this dynamic implication.

This idea is tested across manufacturing industries in the United States by assuming that increased international trade in recent years acted as a form of increased competition in some 
industries. Our approach compares the impact of trade in concentrated versus competitive industries, and enables us to net out the gains in relative female wages that occurred over the period for other reasons. The results indicate that the residual gender wage gap narrowed more rapidly in concentrated industries that experienced a trade shock than in competitive industries that experienced a trade shock. Moreover, the results are consistent across a variety of specifications and data sets.

Although it is unlikely that increased trade had a substantial impact on the overall gender wage gap in the economy - the manufacturing sector currently comprises only about 15 percent of the U.S. workforce - the empirical work in this paper suggests that the impact of trade on the structure of wages should be viewed in a more positive light than has recently been the case. Although trade may increase wage inequality by (modestly) reducing the relative wages of lessskilled workers, at the same time it appears to benefit women by reducing the ability of firms to discriminate. 


\section{References}

Angrist, Joshua D., and Alan B. Krueger. 1999. "Empirical Strategies in Labor Economics." In Orley C. Ashenfelter and David Card, eds., Handbook of Labor Economics Vol. 3A. Amsterdam: Elsevier, pp. 1277-1366.

Ashenfelter, Orley, and Timothy Hannan. 1986. "Sex Discrimination and Product Market Competition: The Case of the Banking Industry." Quarterly Journal of Economics, Vol. 101, No. 1 (February), pp. 149-173.

Bartelsman, Eric J., and Wayne Gray. 1996. "The NBER Manufacturing Productivity Database." NBER Technical Working Paper 205.

Becker, Gary S. 1957, 1971. The Economics of Discrimination. Chicago: The University of Chicago Press.

Bednarzik, Robert W. 1993. "An Analysis of U.S. Industries Sensitive to Foreign Trade, 1982 87." Monthly Labor Review (February), pp. 15-31.

Black, Sandra E., and Philip E. Strahan. 2001. "The Division of Spoils: Rent-Sharing and Discrimination in a Regulated Industry," American Economic Review, Vol. 91, No. 4 (September), pp. 814-31.

Blau, Francine D. 1977. Equal Pay in the Office. Lexington, Mass: Lexington Books.

Blau, Francine D. 1998. "Trends in the Well-Being of American Women, 1970 - 1995." Journal of Economic Literature, Vol. 36, No. 1 (March), pp. 112-65.

Blau, Francine D., and Lawrence M. Kahn. 1997. "Swimming Upstream: Trends in the Gender Wage Differential in the 1980s." Journal of Labor Economics, Vol. 15, No. 1, Part 1 (January), pp. 1-42.

Borjas, George J., and Valerie A. Ramey. 1995. "Foreign Competition, Market Power and Wage Inequality." Quarterly Journal of Economics, Vol. 110, No. 4 (November), pp. 1075-1110.

Bound, John et al. 1994. "Evidence on the Validity of Cross-Sectional and Longitudinal Labor Market Data." Journal of Labor Economics, Vol. 12, No. 3 (July), pp. 345-68.

Campa, Jose Manuel, and Linda S. Goldberg. 1998. "Employment versus Wage Adjustment and the U.S. Dollar." Unpublished paper, Federal Reserve Bank of New York (?).

Feenstra, Robert C. 1996. "U.S. Imports, 1972-1994: Data and Concordances." NBER Working Paper 5515.

Freeman, Richard B. 1995. "Are Your Wages Set in Beijing?" Journal of Economic Perspectives, Vol. 9, No. 2 (Summer), pp. 15-32. 
Gaston, Noel, and Daniel Trefler. 1994. "Protection, Trade, and Wages: Evidence from U.S. Manufacturing." Industrial and Labor Relations Review, Vol. 47, No. 4 (July), pp. 574-92.

Goldberg, Matthew S. 1982. "Discrimination, Nepotism and Long-Run Wage Differentials." Quarterly Journal of Economics, Vol. 97, No. 2 (May), pp. 307-19.

Goldin, Claudia. 1990. Understanding the Gender Gap: An Economic History of American Women. Oxford: Oxford University Press.

Groshen, Erica L. 1991. "The Structure of the Female/Male Wage Differential: Is It Who You Are, What You Do, or Where You Work?" Journal of Human Resources, Vol. 26, No. 3 (Summer), pp. 457-72.

Heckman, James J. 1998. "Detecting Discrimination." The Journal of Economic Perspectives, Vol. 12, No. 2 (Spring), pp. 101 - 116.

Hellerstein, Judith K., David Neumark, and Kenneth R. Troske. 2002. "Market Forces and Sex Discrimination." Journal of Human Resources, Vol. 37, No. 2 (Spring), pp. 353 - 80.

Horn, John T., and J. Gregory Eastman. 1997. "Importing Unionization? The Effects of Import Competition on U.S. Manufacturing Unionization Density, 1974-1992." Unpublished paper.

Jaeger, David A. 1997. "Reconciling the Old and New Census Bureau Education Questions: Recommendations for Researchers." Journal of Business \& Economic Statistics, Vol. 15, No. 3 (July), pp. 300-309.

Jaeger, David A., Susanna Loeb, Sarah E. Turner, and John Bound. 1998. "Coding Geographic Areas across Census Years: Creating Consistent Definitions of Metropolitan Areas." NBER Working Paper 6772.

Katics, Michelle M., and Bruce C. Petersen. 1994. "The Effect of Rising Import Competition on Market Power: A Panel Data Study of U.S. Manufacturing." The Journal of Industrial Economics, Vol. 42, No. 3 (September), pp. 277-86.

Katz, Lawrence F., and Kevin M. Murphy. 1992. "Changes in Relative Wages, 1963 - 1987 : Supply and Demand Factors." Quarterly Journal of Economics, Vol. 107, No. 1 (February), pp. 35-78.

Kletzer, Lori G. 1996a. "The Impact of Foreign Competition on Occupational Employment and Wages in U.S. Manufacturing, 1971-1992." Unpublished paper, University of California, Santa Cruz.

Kletzer, Lori G. 1996b. "Gender Differences in the Incidence and Consequences of Job Displacement from Import-Sensitive Industries." Unpublished paper, University of California, Santa Cruz. 
Kruse, Douglas L. 1988. "International Trade and the Labor Market Experience of Displaced Workers." Industrial and Labor Relations Review, Vol. 41, No. 3 (April), pp. 402-417.

Levinsohn, James. 1993. "Testing the Imports-As-Market-Discipline Hypothesis." Journal of International Economics, Vol. 35, No. 1-2 (August), pp. 1-22.

Murphy, Kevin M., and Finis Welch. 1991. "The Role of International Trade in Wage Differentials." In Marvin Kosters, ed., Workers and Their Wages. Washington, D.C.: The AEI Press, pp. 39-69.

Neumark, David, with the assistance of Roy J. Bank and Kyle D. Van Nort. 1996. "Sex Discrimination in Restaurant Hiring: An Audit Study." Quarterly Journal of Economics, Vol. 111, No. 3, pp. 915-941.

O'Neill, June, and Solomon Polachek. 1993. "Why the Gender Gap in Wages Narrowed in the 1980s." Journal of Labor Economics, Vol. 11, No. 1 (Part 1), pp. 205-28.

Revenga, Ana. 1992. "Exporting Jobs? The Impact of Foreign Competition on Employment and Wages in U.S. Manufacturing." Quarterly Journal of Economics, Vol. 107, No. 1 (February), pp. 255-84.

Ruggles, Steven, and Matthew Sobek. 1997. Integrated Public Use Microdata Series: Version 2.0 (Minneapolis: Historical Census Projects) University of Minnesota.

Weinberger, Catherine J. 1998. "Race and Gender Wage Gaps in the Market for Recent College Graduates." Industrial Relations, Vol. 37, No. 1 (January), pp. 67-84.

Wood, Adrian. 1994. North-South Trade, Employment, and Inequality. Oxford: Clarendon Press.

Wood, Robert G., Mary E. Corcoran, and Paul N. Courant. 1993. "Pay Differences Among the Highly Paid: The Male-Female Earnings Gap in Lawyers' Salaries." Journal of Labor Economics, Vol. 11, No. 3 (July), pp. 417-41. 
Figure 1. Trends in female/male median wages (full-time workers) and imports as a share of GDP (1992 dollars)

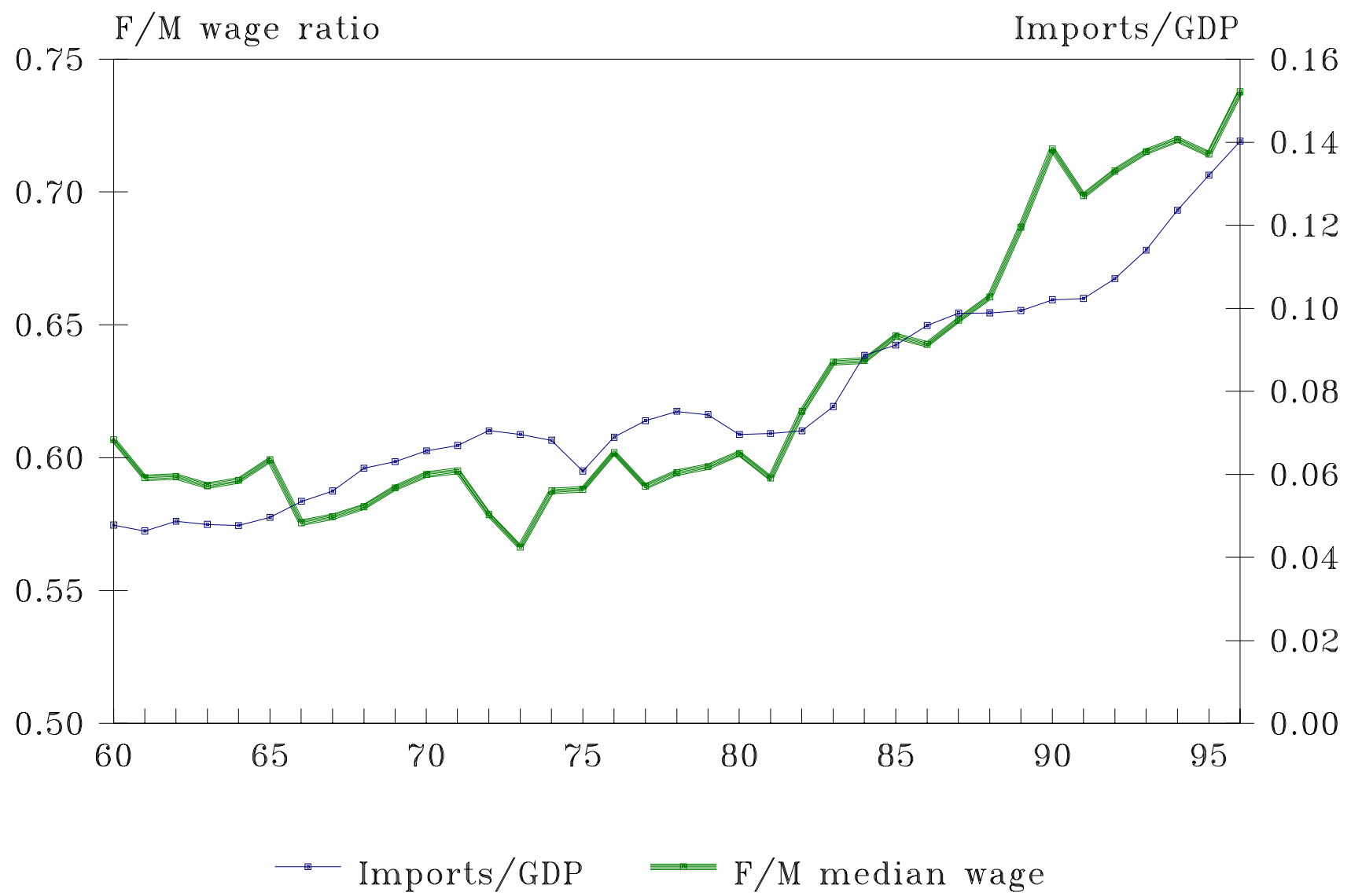

Sources: Gender wage ratio: U.S. Bureau of the Census, Current Population Reports, Imports/GDP: U.S. Dept. of Commerce, National Income and Product Accounts 
Table 1

Industry Level Regression Results, CPS

(Standard errors in Parenthesis)

[Standardized Coefficient in Brackets]

\begin{tabular}{|c|c|c|c|c|c|}
\hline $\begin{array}{l}\text { Dependent } \\
\text { Variable: } \\
\text { Change in } \\
\text { Residual Gender } \\
\text { Wage Gap }\end{array}$ & $\begin{array}{l}\text { 1976-1993 } \\
\text { Weekly } \\
\text { Earnings }\end{array}$ & $\begin{array}{l}\text { 1976-1993 } \\
\text { Hourly } \\
\text { Earnings }\end{array}$ & $\begin{array}{l}\text { 1976-1993 } \\
\text { Weekly } \\
\text { Earnings }\end{array}$ & $\begin{array}{c}9 \text { year } \\
\text { differences } \\
\text { Weekly } \\
\text { Earnings }\end{array}$ & $\begin{array}{c}6 \text { year } \\
\text { differences } \\
\text { Weekly } \\
\text { Earnings }\end{array}$ \\
\hline $\begin{array}{l}\text { Concentrated } \\
\text { industry }^{a *} \text { Change } \\
\text { in import share }\end{array}$ & $\begin{array}{c}-.66 * * \\
(.28) \\
{[-.249]}\end{array}$ & $\begin{array}{c}-.65 * * \\
(.28) \\
{[-.248]}\end{array}$ & & $\begin{array}{c}-.64 * * \\
(.29)\end{array}$ & $\begin{array}{l}-.46 \\
(.32)\end{array}$ \\
\hline $\begin{array}{l}\text { Price-Cost } \\
\text { Margin*Change in } \\
\text { import share }\end{array}$ & & & $\begin{array}{c}-4.55^{* *} \\
(2.29)\end{array}$ & & \\
\hline $\begin{array}{l}\text { Concentrated } \\
\text { industry }\end{array}$ & $\begin{array}{l}.19 * * \\
(.06)\end{array}$ & $\begin{array}{l}.19 * * \\
(.06)\end{array}$ & & $\begin{array}{l}.09 * * \\
(.03)\end{array}$ & $\begin{array}{l}.06 * * \\
(.03)\end{array}$ \\
\hline Price-Cost Margin & & & $\begin{array}{l}-.12 \\
(.29)\end{array}$ & & \\
\hline $\begin{array}{l}\text { Change in import } \\
\text { share }\end{array}$ & $\begin{array}{l}.27^{* *} \\
(.13)\end{array}$ & $\begin{array}{l}.27 * * \\
(.13)\end{array}$ & $\begin{array}{l}1.31^{*} \\
(.57)\end{array}$ & $\begin{array}{l}.22 \\
(.16)\end{array}$ & $\begin{array}{c}.17 \\
(.17)\end{array}$ \\
\hline 1988 dummy & & & & & $\begin{array}{l}-.001 \\
(.028)\end{array}$ \\
\hline 1993 dummy & & & & $\begin{array}{l}.02 \\
(.02)\end{array}$ & $\begin{array}{l}.003 \\
(.028)\end{array}$ \\
\hline $\mathrm{N}=$ & 63 & 63 & 63 & 123 & 188 \\
\hline Adjusted $\mathrm{R}^{2}=$ & .1253 & .1260 & .1150 & .0287 & -.0005 \\
\hline \multicolumn{6}{|c|}{$\begin{array}{l}\text { A concentrated industry is defined as an industry with a four-firm concentration ratio greater than or equal to } .40 \text { in the } 197 \\
\text { Census of Manufacturers. } \\
\text { Import share is defined as imports/domestic shipments. } \\
* \text { is statistically significant at the } 5 \% \text { level of significance. } \\
* \text { is statistically significant at the } 10 \% \text { level of significance } \\
\text { The observations are weighted by the inverse of the sampling variance of the dependent variable. } \\
\text { Standardized coefficients are the coefficient*(standard deviation of independent variable/standard deviation of } \\
\text { dependent variable) }\end{array}$} \\
\hline
\end{tabular}


Table 2

Industry Level Regression Results

(Standard errors in Parenthesis)

[Standardized Coefficient in Brackets]

\begin{tabular}{|c|c|c|c|}
\hline \multirow[b]{2}{*}{$\begin{array}{l}\text { Dependent Variable: } \\
\text { Change in Residual Gender } \\
\text { Wage Gap }\end{array}$} & \multicolumn{2}{|c|}{$\begin{array}{c}\text { CPS Outgoing Rotation } \\
1979-1993\end{array}$} & \multirow{2}{*}{$\begin{array}{c}\text { Census } \\
1980-1990 \\
\text { Weekly Earnings }\end{array}$} \\
\hline & Weekly Earnings & Hourly Earnings & \\
\hline $\begin{array}{l}\text { Concentrated industry }{ }^{\mathrm{a}} \\
\text { Change in import share }\end{array}$ & $\begin{array}{c}-.24 \\
(.15) \\
{[-.305]}\end{array}$ & $\begin{array}{c}-.25^{*} \\
(.15) \\
{[-.317]}\end{array}$ & $\begin{array}{c}-.13 * \\
(.07) \\
{[-.302]}\end{array}$ \\
\hline Concentrated industry & $\begin{array}{l}.07 * * \\
(.03)\end{array}$ & $\begin{array}{l}.07 * * \\
(.03)\end{array}$ & $\begin{array}{l}.02 * \\
(.01)\end{array}$ \\
\hline Change in import share & $\begin{array}{c}.04 \\
(.09)\end{array}$ & $\begin{array}{l}.04 \\
(.09)\end{array}$ & $\begin{array}{l}.06^{*} \\
(.03)\end{array}$ \\
\hline $\mathrm{N}=$ & 64 & 64 & 74 \\
\hline Adjusted $\mathrm{R}^{2}=$ & .0344 & .0415 & .0321 \\
\hline
\end{tabular}

${ }^{a}$ A concentrated industry is defined as an industry with a four-firm concentration ratio greater than or equal to .40 in the 1977 Census of Manufacturers.

${ }^{\mathrm{b}}$ Import share is defined as imports/domestic shipments.

$* *$ is statistically significant at the $5 \%$ level of significance.

$*$ is statistically significant at the $10 \%$ level of significance

The observations are weighted by the inverse of the sampling variance of the dependent variable. 
Table 3

MSA Level Regression Results

(Standard errors in Parenthesis)

[Standardized Coefficient in Brackets]

\begin{tabular}{|c|c|c|c|}
\hline \multirow[b]{2}{*}{$\begin{array}{l}\text { Dependent Variable: } \\
\text { Residual Change in the Gender } \\
\text { Wage Gap }\end{array}$} & \multicolumn{2}{|c|}{$\begin{array}{c}\text { CPS } \\
1976-1993\end{array}$} & \multirow{2}{*}{$\begin{array}{c}\text { Census } \\
\text { 1980-1990 } \\
\text { Weekly Earnings }\end{array}$} \\
\hline & Weekly Earnings & Hourly Earnings & \\
\hline $\begin{array}{l}\text { Percent in concentrated } \\
\text { industry } * \text { Change in import } \\
\text { share }^{\mathrm{b}}\end{array}$ & $\begin{array}{l}-6.25^{*} \\
(3.37) \\
{[-1.10]}\end{array}$ & $\begin{array}{l}-6.42 * \\
(3.31) \\
{[-1.13]}\end{array}$ & $\begin{array}{l}-2.97 \\
(2.51) \\
{[-.594]}\end{array}$ \\
\hline Percent in concentrated industry & $\begin{array}{l}.80 * \\
(.47)\end{array}$ & $\begin{array}{l}.80 * \\
(.46)\end{array}$ & $\begin{array}{l}.21 \\
(.19)\end{array}$ \\
\hline Change in import share & $\begin{array}{l}2.59^{*} \\
(1.35)\end{array}$ & $\begin{array}{c}2.69 * * \\
(1.34)\end{array}$ & $\begin{array}{c}1.51 \\
(1.02)\end{array}$ \\
\hline Change in unemployment rate & $\begin{array}{l}.36 \\
(.93)\end{array}$ & $\begin{array}{l}.30 \\
(.92)\end{array}$ & $\begin{array}{l}-.25 \\
(.33)\end{array}$ \\
\hline $\mathrm{N}=$ & 43 & 43 & 132 \\
\hline Adjusted $\mathrm{R}^{2}=$ & -.0027 & -.0056 & -.0037 \\
\hline
\end{tabular}

${ }^{a}$ A concentrated industry is defined as an industry with a four-firm concentration ratio greater than or equal to .40 in the 1977 Census of Manufacturers. 'Percent in concentrated industry' is the employment-weighted average of the share of workers employed in a concentrated industry in each MSA.

${ }^{\mathrm{b}}$ Import share is defined as the employment-weighted average of the import share in each industry in the MSA.

$* *$ is statistically significant at the $5 \%$ level of significance.

* is statistically significant at the $10 \%$ level of significance

The observations are weighted by the inverse of the sampling variance of the dependent variable. 
Table 4

Regression Results, CPS

Specification Checks

(Standard errors in Parenthesis)

[Standardized Coefficient in Brackets]

\begin{tabular}{|c|c|c|c|c|c|c|}
\hline \multirow[b]{2}{*}{ Dependent Variable: } & \multirow[b]{2}{*}{$\begin{array}{c}\text { Unions } \\
\text { Change in } \\
\text { Residual } \\
\text { Gender Wage } \\
\text { Gap } \\
\text { 1976-1993 } \\
\text { weekly wages } \\
\text { (1) }\end{array}$} & \multicolumn{2}{|c|}{ Computer Use } & \multicolumn{2}{|c|}{ Employment } & \multirow[b]{2}{*}{$\begin{array}{c}\text { Minority } \\
\text { Change in } \\
\text { Residual } \\
\text { white/nonwhite } \\
\text { wage gap } \\
\text { CPS-ORG } \\
\text { 1979-93 } \\
(6)\end{array}$} \\
\hline & & $\begin{array}{l}\text { Change in } \\
\text { \% Comp- } \\
\text { uter Use } \\
\text { at Work } \\
198 \\
\text { (2) }\end{array}$ & $\begin{array}{l}\text { Change in } \\
\text { Residual } \\
\text { Gender } \\
\text { Wage Gap } \\
1993 \\
\text { (3) }\end{array}$ & $\begin{array}{l}\text { Change in } \\
\text { Percentage of } \\
\text { Women } \\
\text { Employees } \\
19 \\
\text { em }\end{array}$ & $\begin{array}{c}\text { Change in } \\
\text { Percentage of } \\
\text { Managers who are } \\
\text { Women } \\
\text { 6-1993 } \\
\text { oyment } \\
\text { (5) }\end{array}$ & \\
\hline $\begin{array}{l}\text { Concentrated } \\
\text { industry }{ }^{a} \text { Change } \\
\text { in import share }\end{array}$ & $\begin{array}{c}-.95 * \\
(.51) \\
{[-.315]}\end{array}$ & $\begin{array}{l}-.19 \\
(.15)\end{array}$ & $\begin{array}{l}-.92 * * \\
(.30)\end{array}$ & $\begin{array}{c}.17 \\
(.12) \\
{[.261]}\end{array}$ & $\begin{array}{l}.40 * * \\
(.14)\end{array}$ & $\begin{array}{c}-.35 \\
(.26) \\
{[-.318]}\end{array}$ \\
\hline $\begin{array}{l}\text { Concentrated } \\
\text { industry }\end{array}$ & $\begin{array}{l}.22 * * \\
(.08)\end{array}$ & $\begin{array}{l}.04^{*} \\
(.02)\end{array}$ & $\begin{array}{l}.15^{* *} \\
(.04)\end{array}$ & $\begin{array}{l}.001 \\
(.02)\end{array}$ & $\begin{array}{r}-.021 \\
(.03)\end{array}$ & $\begin{array}{l}.01 \\
(.04)\end{array}$ \\
\hline $\begin{array}{l}\text { Change in import } \\
\text { share }\end{array}$ & $\begin{array}{l}.29 * * \\
(.14)\end{array}$ & $\begin{array}{c}-.22 * * \\
(.09)\end{array}$ & $\begin{array}{l}.26 \\
(.18)\end{array}$ & $\begin{array}{l}-.15 \\
(.06)\end{array}$ & $\begin{array}{l}-.12 \\
(.09)\end{array}$ & $\begin{array}{l}.06 \\
(.17)\end{array}$ \\
\hline $\begin{array}{l}\text { Change in } \\
\text { unionization }\end{array}$ & $\begin{array}{l}.07 \\
(.30)\end{array}$ & & & & & \\
\hline $\mathrm{N}=$ & 58 & 63 & 62 & 66 & 67 & 65 \\
\hline Adjusted $\mathrm{R}^{2}=$ & .1141 & .1850 & .1455 & .0702 & .1210 & .0098 \\
\hline
\end{tabular}

${ }^{a}$ A concentrated industry is defined as an industry with a four-firm concentration ratio greater than or equal to .40 in the 1977 Census of Manufacturers.

${ }^{\mathrm{b}}$ Import share is defined as imports/domestic shipments.

** is statistically significant at the $5 \%$ level of significance. 
* is statistically significant at the $10 \%$ level of significance

The observations are weighted by the inverse of the sampling variance of the dependent variable.

\section{Appendix Table 1 Summary Statistics}

(Standard Deviations in Parentheses)

\begin{tabular}{|c|c|c|c|c|c|}
\hline & \multicolumn{2}{|c|}{ Industry } & \multirow[b]{2}{*}{$\begin{array}{l}\text { Outgoing } \\
\text { Rotation }\end{array}$} & \multicolumn{2}{|c|}{ MSA } \\
\hline & $\begin{array}{c}\text { CPS } \\
1976-1993\end{array}$ & Census data & & $\begin{array}{c}\text { CPS } \\
1976-1993\end{array}$ & Census data \\
\hline $\begin{array}{l}\text { Change in residual gender } \\
\text { wage gap in manufacturing } \\
\text { (weekly earnings) }\end{array}$ & $\begin{array}{l}-.138 \\
(.157)\end{array}$ & $\begin{array}{l}-.066 \\
(.031)\end{array}$ & $\begin{array}{l}-.068 \\
(.089)\end{array}$ & $\begin{array}{l}-.186 \\
(.159)\end{array}$ & $\begin{array}{l}-.075 \\
(.060)\end{array}$ \\
\hline $\begin{array}{l}\text { Change in residual gender } \\
\text { wage gap in manufacturing } \\
\text { (hourly earnings) }\end{array}$ & $\begin{array}{l}-.135 \\
(.156)\end{array}$ & & $\begin{array}{l}-.068 \\
(.089)\end{array}$ & $\begin{array}{l}-.185 \\
(.159)\end{array}$ & \\
\hline $\begin{array}{l}\text { Percent in concentrated } \\
\text { industry*change in import } \\
\text { share }\end{array}$ & $\begin{array}{l}.052 \\
(.101)\end{array}$ & $\begin{array}{c}.037 \\
(.072)\end{array}$ & $\begin{array}{l}.051 \\
(.113)\end{array}$ & $\begin{array}{l}.043 \\
(.028)\end{array}$ & $\begin{array}{l}.029 \\
(.012)\end{array}$ \\
\hline $\begin{array}{l}\text { Percent in concentrated } \\
\text { industry }\end{array}$ & $\begin{array}{l}.309 \\
(.466)\end{array}$ & $\begin{array}{l}.354 \\
(.481)\end{array}$ & $\begin{array}{l}.301 \\
(.462)\end{array}$ & $\begin{array}{l}.349 \\
(.152)\end{array}$ & $\begin{array}{l}.376 \\
(.113)\end{array}$ \\
\hline Change in import share & $\begin{array}{c}.097 \\
(.275)\end{array}$ & $\begin{array}{l}.079 \\
(.115)\end{array}$ & $\begin{array}{l}.086 \\
(.270)\end{array}$ & $\begin{array}{l}.121 \\
(.045)\end{array}$ & $\begin{array}{l}.076 \\
(.020)\end{array}$ \\
\hline $\begin{array}{l}\text { Change in union } \\
\text { membership }\end{array}$ & $\begin{array}{l}-.137 \\
(.078)\end{array}$ & $\begin{array}{l}-.032 \\
(.053)\end{array}$ & $\begin{array}{l}-.130 \\
(.069)\end{array}$ & $\begin{array}{l}-.175 \\
(.037)\end{array}$ & $\begin{array}{l}-.047 \\
(.029)\end{array}$ \\
\hline $\begin{array}{l}\text { Change in unemployment } \\
\text { rate }\end{array}$ & & & & $\begin{array}{l}.001 \\
(.027)\end{array}$ & $\begin{array}{l}-.002 \\
(.016)\end{array}$ \\
\hline $\mathrm{N}=$ & 63 & 74 & 64 & 43 & 132 \\
\hline
\end{tabular}




\section{Appendix Table A}

\begin{tabular}{|c|c|c|c|}
\hline \multicolumn{2}{|c|}{ Concentrated Industries } & \multicolumn{2}{|c|}{ Non-concentrated Industries } \\
\hline $\begin{array}{l}\text { CIC } \\
\text { Code }\end{array}$ & Industry: Not Trade Impacted ${ }^{l}$ & $\begin{array}{l}\text { CIC } \\
\text { Code } \\
\end{array}$ & Industry: Not Trade Impacted \\
\hline $\begin{array}{l}110 \\
130 \\
140 \\
182 \\
250 \\
262 \\
280 \\
291 \\
292 \\
310 \\
311 \\
352 \\
360 \\
361\end{array}$ & $\begin{array}{l}\text { grain mill products } \\
\text { tobacco manufacturers } \\
\text { dyeing \& finishing textiles, except wool \& knit } \\
\text { soaps, cosmetics } \\
\text { glass \& glass products } \\
\text { misc. nonmetallic mineral \& stone products } \\
\text { other primary metal industries } \\
\text { metal forgings \& stampings } \\
\text { ordnance } \\
\text { engines \& turbines } \\
\text { farm \& machinery equipment } \\
\text { aircraft \& parts } \\
\text { ship \& boat building \& repairing } \\
\text { railroad \& locomotive equipment }\end{array}$ & $\begin{array}{l}100 \\
101 \\
102 \\
111 \\
112 \\
120 \\
121 \\
141 \\
142 \\
150 \\
160 \\
161 \\
162 \\
181 \\
190 \\
191 \\
192 \\
200 \\
201 \\
241 \\
242 \\
251 \\
271 \\
282 \\
290 \\
300 \\
341 \\
370 \\
372\end{array}$ & $\begin{array}{l}\text { meat products } \\
\text { dairy products } \\
\text { canned \& preserved fruits \& vegetables } \\
\text { bakery products } \\
\text { sugar \& confectionery products } \\
\text { beverage industries } \\
\text { misc. food prep. \& kindred products } \\
\text { floor coverings, except hard surfaces } \\
\text { yarn, thread \& fabric mills } \\
\text { misc. textile mill products } \\
\text { pulp, paper, paperboard mills } \\
\text { misc. paper \& pulp products } \\
\text { paperboard containers \& boxes } \\
\text { drugs } \\
\text { paints, varnishes, related products } \\
\text { agricultural chemicals } \\
\text { industrial \& misc. chemicals } \\
\text { petroleum refining } \\
\text { misc. petroleum \& coal products } \\
\text { misc. wood products } \\
\text { furniture \& fixtures } \\
\text { cement, concrete, gypsum, plaster products } \\
\text { iron \& steel foundries } \\
\text { fabricated structural metal products } \\
\text { screw machine products } \\
\text { misc. fabricated metal products } \\
\text { radio, T.V., communications equipment } \\
\text { cycles \& misc. transportation equipment } \\
\text { optical \& health services supplies }\end{array}$ \\
\hline $\begin{array}{l}\text { CIC } \\
\text { Code } \\
\end{array}$ & Industry: Trade Impacted & $\begin{array}{l}\text { CIC } \\
\text { Code } \\
\end{array}$ & Industry: Trade Impacted \\
\hline $\begin{array}{l}380 \\
252 \\
261 \\
312 \\
321 \\
322 \\
340 \\
342 \\
351\end{array}$ & $\begin{array}{l}\text { photographic supplies \& equipment } \\
\text { structural clay products } \\
\text { pottery \& related products } \\
\text { construction \& material handling machines } \\
\text { office \& accounting machines } \\
\text { electronic computing equipment } \\
\text { household appliances } \\
\text { electrical machinery, equipment, supplies } \\
\text { motor vehicles and motor vehicle equipment }\end{array}$ & $\begin{array}{l}132 \\
151 \\
152 \\
211 \\
221 \\
222 \\
281 \\
320 \\
331 \\
371 \\
391\end{array}$ & $\begin{array}{l}\text { knitting mills } \\
\text { apparel \& accessories, except knit } \\
\text { misc. fabricated textile products } \\
\text { other rubber products, plastics footwear, belting } \\
\text { footwear, except leather \& plastic } \\
\text { leather products, except footwear } \\
\text { cutlery, hand tools, other hardware } \\
\text { metalworking machinery } \\
\text { machinery, except electrical } \\
\text { scientific \& controlling instruments } \\
\text { misc. manufacturing industries }\end{array}$ \\
\hline
\end{tabular}

${ }^{1}$ A trade-impacted industry is defined as one in which the import share increased by at least 10 between 1976 and 1993 . A concentrated industry is defined as having a four-firm concentration ratio of greater than .40 in 1977. 